\title{
Estimation of Glomerular Filtration Rate Based on Serum Cystatin $C$ versus Creatinine in a Uruguayan Population
}

\author{
Inés Lujambio, ${ }^{1,2}$ Mariana Sottolano, ${ }^{1,2,3}$ Leonella Luzardo, ${ }^{1,2,3}$ Sebastián Robaina, ${ }^{1,2}$ \\ Nadia Krul, ${ }^{4}$ Lutgarde Thijs, ${ }^{5}$ Florencia Carusso, ${ }^{1}$ Alicia da Rosa, ${ }^{1,2}$ \\ Ana Carina Ríos, ${ }^{4}$ Alicia Olascoaga, ${ }^{4}$ Mariela Garau, ${ }^{6}$ Liliana Gadola, ${ }^{2,3}$ \\ Oscar Noboa, ${ }^{1,3}$ Jan A. Staessen, ${ }^{5,7}$ and José Boggia ${ }^{1,2,3}$ \\ ${ }^{1}$ Unidad de Hipertensión Arterial, Hospital de Clínicas Dr. Manuel Quintela, Universidad de la República, \\ Avenida Italia 2870, 11600 Montevideo, Uruguay \\ ${ }^{2}$ Departamento de Fisiopatología, Universidad de la República, Montevideo, Uruguay \\ ${ }^{3}$ Centro de Nefrología, Universidad de la República, Montevideo, Uruguay \\ ${ }^{4}$ Departamento Laboratorio de Patología Clínica at Hospital de Clínicas, Universidad de la República, Montevideo, Uruguay \\ ${ }^{5}$ Department of Cardiovascular Sciences, Studies Coordinating Centre, Research Unit Hypertension and Cardiovascular Epidemiology, \\ University of Leuven (KU Leuven), Leuven, Belgium \\ ${ }^{6}$ Departamento de Métodos Cuantitativos, Facultad de Medicina, Universidad de la República, Montevideo, Uruguay \\ ${ }^{7}$ Department of Epidemiology, Maastricht University, Maastricht, The Netherlands
}

Correspondence should be addressed to José Boggia; jboggia@hc.edu.uy

Received 9 June 2014; Revised 31 July 2014; Accepted 8 August 2014; Published 24 August 2014

Academic Editor: Michael J. Ross

Copyright (C) 2014 Inés Lujambio et al. This is an open access article distributed under the Creative Commons Attribution License, which permits unrestricted use, distribution, and reproduction in any medium, provided the original work is properly cited.

\begin{abstract}
Background. Estimation of glomerular filtration rate (eGFR) from biomarkers has evolved and multiple equations are available to estimate renal function at bedside. Methods. In a random sample of 119 Uruguayans (54.5\% women; 56.2 years (mean)), we used Bland and Altman's method and Cohen's kappa statistic to assess concordance on a continuous or categorical (eGFR $<60$ versus $\geq 60 \mathrm{~mL} / \mathrm{min} / 1.73 \mathrm{~m}^{2}$ ) scale between GFFR $_{\text {cys }}$ (reference) and eGFR derived from serum creatinine according to the Modification

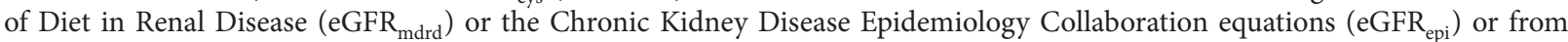
both serum cystatin $\mathrm{C}$ and creatinine $\left(\mathrm{eGFR}_{\text {mix }}\right)$. Results. In all participants, $\mathrm{eGFR}_{\mathrm{mdrd}}$, $\mathrm{eGFR}_{\mathrm{epi}}$, and $\mathrm{eGFR}_{\mathrm{mix}} \mathrm{were}_{\mathrm{m}}$, respectively, 9.7, 11.5 , and $5.6 \mathrm{~mL} / \mathrm{min} / 1.73 \mathrm{~m}^{2}$ higher $(P<0.0001)$ than $\mathrm{eGFR}_{\text {cys }}$. The prevalence of eGFR $<60 \mathrm{~mL} / \mathrm{min} / 1.73 \mathrm{~m}^{2}$ was the highest

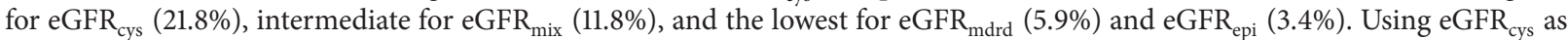
reference, we found only fair agreement with the equations based on creatinine (Cohen's kappa statistic 0.15 to 0.23 ). Conclusion. Using different equations we reached clinically significant differences in the estimation of renal function. eGFR $_{\text {cys }}$ provides lower estimates, resulting in higher prevalence of eGFR $<60 \mathrm{~mL} / \mathrm{min} / 1.73 \mathrm{~m}^{2}$.
\end{abstract}

\section{Introduction}

The glomerular filtration rate (GFR) is the most widely used indicator of overall renal function. The GFR can be measured by clearance of an ideal, usually exogenous, filtration marker such as inulin, iothalamate, EDTA, diethylene triamine pentaacetic acid, or iohexol. The clearance of endogenous markers such as creatinine or blood urea nitrogen can overestimate or underestimate the GFR. All these methods have the drawback to be complex and require 24-hour urine collection, which is not always practicable in day-to-day clinical practice. A more pragmatic approach is to estimate GFR from equations based on serum creatinine [1,2].

More recently, experts proposed cystatin $\mathrm{C}$ as an alternative to creatinine [3]. Cystatin $C$ is a nonglycosylated protein with low molecular mass $(13.3 \mathrm{kDa})$ generated by all nucleated cells of the body at a constant rate, is freely filtered by the glomerulus, and is not secreted by renal tubules 
but completely reabsorbed with subsequent degradation by proximal tubular cells $[4,5]$. For those properties cystatin C is an endogenous surrogate of GFR. Compared with serum creatinine, cystatin $\mathrm{C}$ levels are less dependent on ethnicity, sex, age, and muscle mass or protein intake. Moreover, as serum creatinine, cystatin $\mathrm{C}$ is an independent predictor of cardiovascular and overall mortality [6].

Compared to GFR measurement based on the renal clearance of exogenous markers, estimated glomerular filtration rate (eGFR) is more precise if derived from both cystatin $\mathrm{C}$ and creatinine levels in serum [3]. This observation was consistent across sex, age, and diabetes mellitus [7]. On the other hand, measurement of cystatin C is costly and eGFR based on cystatin $\mathrm{C}$ needs further validation across a broad spectrum of populations with or without chronic kidney disease. The purpose of our current study was to compare estimates of eGFR based on cystatin $\mathrm{C}$ and creatinine in randomly recruited Uruguayans, using eGFR derived from cystatin $\mathrm{C}$ as reference.

\section{Materials and Methods}

2.1. Study Population. GEnotipo Fenotipo y Ambiente de la HiperTension en UruguaY (GEFA-HT-UY) is a prospective cohort study started in April 2012 conducted by the Unidad de Hipertensión Arterial, Hospital de Clínicas Dr. Manuel Quintela, Universidad de la República, Montevideo, Uruguay [8]. The Ethics Committee of the University Hospital approved the study protocol and all participants gave informed written consent. The aim of the study is to explore the relation of blood pressure with genetic and environmental factors in a representative Uruguayan population sample. Nuclear families were randomly recruited from the inhabitants of a geographically defined area, the Juana de América housing project, located about $10 \mathrm{~km}$ from downtown Montevideo. A nuclear family had to include at least one parent and two siblings. The minimum age was 18 , without upper age limit. Family members living at the same address or within a distance of no more than $10 \mathrm{~km}$ were eligible. We invited participants by telephone. The participation rate among eligible subjects was $72.7 \%$. In November 2013, 149 people had participated, of whom we excluded 30 from the present analysis, because either cystatin $\mathrm{C}$ or creatinine had not been measured $(n=22)$ or because they had not yet completed the physical examination $(n=8)$. Thus, the number of participants analysed statistically totalled 119.

2.2. Field Work. The examinations took place at a field centre located within the neighbourhood. Trained observers administered a standardised questionnaire inquiring into each participant's medical history, smoking and drinking habits, and intake of medications. They measured blood pressure according to the European guidelines. After participants had rested for 5 minutes in the sitting position, the observers obtained five consecutive blood pressure readings (phase $\mathrm{V}$ diastolic pressure) to the nearest $2 \mathrm{~mm} \mathrm{Hg}$, using mercury sphygmomanometers. Standard cuffs had a $12 \times 24 \mathrm{~cm}$ inflatable portion, but if upper arm girth exceeded $31 \mathrm{~cm}$, larger cuffs with $15 \times 35 \mathrm{~cm}$ bladders were used. Pulse pressure is the difference of systolic minus diastolic blood pressure. Mean arterial pressure is diastolic pressure plus one-third of pulse pressure. For analysis, the five blood pressure readings were averaged. Hypertension was an office blood pressure of at least $140 \mathrm{~mm} \mathrm{Hg}$ systolic or $90 \mathrm{~mm} \mathrm{Hg}$ diastolic or use of antihypertensive drugs. The observers measured body height to the nearest $0.5 \mathrm{~cm}$ with a pliable measurer and the participant standing against the wall. Participants wore light indoor clothing without shoes for body weight measurements. Body mass index was weight in kilograms divided by square of height in meters. Venous blood samples were obtained after at least 12 hours fasting and were kept at $4^{\circ} \mathrm{C}$ and within 2 hours period were analysed for serum levels of cystatin C, creatinine, cholesterol, and glucose. Diabetes mellitus was the use of anti-diabetic drugs or a fasting glucose $\geq$ $126 \mathrm{mg} / \mathrm{dL}$ (7 $\mathrm{mmol} / \mathrm{L})$.

2.3. Arterial Phenotypes. After the participants had rested $15 \mathrm{~min}$ in the supine position, we recorded during an $8 \mathrm{~s}$ period the radial waveforms at the right side by applanation tonometry. We used a high-fidelity SPC-301 micromanometer (Millar Instruments, Houston, TX) interfaced with a computer running SphygmoCor software, version 8.2 (AtCor Medical, West Ryde, New South Wales, Australia). We discarded recordings when the systolic or diastolic variability of consecutive waveforms exceeded $5 \%$ or the amplitude of the pulse wave signal was less than $80 \mathrm{mV}$. We calibrated the radial pulse wave on the brachial blood pressure [9]. From the radial signal, the SphygmoCor software calculates the aortic pulse wave by means of a validated generalised transfer function $[10,11]$. The augmentation index was the ratio of the second to the first peak of the pressure wave expressed as a percentage.

Aortic pulse wave velocity was measured by sequential ECG-gated recordings of the arterial pressure waveform at the carotid and femoral arteries [12]. We measured the distances from the suprasternal notch to the carotid sampling site (distance $A$ ) and from the suprasternal notch to the femoral sampling site (distance $B$ ). Pulse wave travel distance was calculated as distance $B$ minus distance $A$. Pulse transit time was the average of 10 consecutive beats. Pulse wave velocity was the distance in meters divided by the transit time in seconds [12].

2.4. Laboratory Methods. Serum cystatin C was measured by a particle-enhanced turbidimetric immunoassay (PETIA), (COBAS, Roche diagnostics, Germany). The latex enhanced particles coated with anticystatin $\mathrm{C}$ antibodies in the reagent agglutinate with the human cystatin $\mathrm{C}$ in the sample. The degree of the turbidity caused by the aggregate was determined turbidimetrically at $546 \mathrm{~nm}$. This assay has a detection limit of $0.4 \mathrm{mg} / \mathrm{L}$ and a coefficient of variation of $1.3 \%$. Serum creatinine was measured by modified kinetic Jaffé methods with the modifications described elsewhere [13, 14]. The detection limit is $0.17 \mathrm{mg} / \mathrm{dL}$ and the coefficient of variation was $1.6 \%$. We use a creatinine method that has calibration traceable to an IDMS reference measurement procedure according to present recommendations $[15,16]$. 
2.5. Estimated Glomerular Filtration Rate. We estimated GFR using four equations. First, we computed eGFR from serum cystatin $\mathrm{C}$ eGFR $\mathrm{Gys}_{\text {c }}$, as described by Inker and colleagues [3]. Next, we calculated eGFR from serum creatinine according to the IDMS-traceable MDRD Study Equation (MDRD) $[17,18]$ formula $\left(e \mathrm{GFR}_{\mathrm{mdrd}}\right)$ or the Chronic Kidney Disease Epidemiology Collaboration (CKD-EPI) [2] equation $\left(\mathrm{eGFR}_{\mathrm{epi}}\right)$. Finally, as proposed by Inker and colleagues, [3] we also derived eGFR from both serum cystatin $\mathrm{C}$ and serum creatinine $\left(\mathrm{eGFR}_{\text {mix }}\right)$. All aforementioned estimates [1-3] account for sex and age and with the exception of eGFR $_{\text {cys }}$ also consider ethnicity (black versus nonblack). This particular characteristic was irrelevant for our current study as our participants only included Whites mainly of European descent. Table S1 in the online data supplement provides detailed information on each formula (see Table S1 in Supplementary Material available online at http://dx.doi.org/10.1155/2014/837106). In our current analyses, we compared findings based on the various methods to estimate GFR against $\mathrm{eGFR}_{\text {cys }}$ as the referent method. Low glomerular filtration rate (L-GFR) was an eGFR < $60 \mathrm{~mL} / \mathrm{min} / 1.73 \mathrm{~m}^{2}$ based on a single determination of each biomarker.

2.6. Statistical Analysis. For database management and statistical analysis, we used SAS software, version 9.3 (SAS Institute, Cary, NC). First, in exploratory analyses, we assessed the characteristics of participants by fourths of

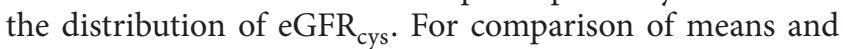
proportions, we applied Student's $t$-test (or ANOVA) and the $\chi^{2}$ statistic, respectively. We assessed agreement between paired measurements on a continuous scale by Bland and Altman's method [19]. To allow comparison with literature data, we also computed correlation coefficients. The National Kidney Foundation KDOQI guideline proposes a threshold of $60 \mathrm{~mL} / \mathrm{min} / 1.73 \mathrm{~m}^{2}$ to diagnose chronic kidney disease [20]. In categorical analyses, we, therefore, also assessed the agreement between equations to dichotomize subjects in LGFR or not-L-GFR using Cohen's kappa statistic [21]. A kappa value of 0.20 or less indicates slight agreement, 0.20 to 0.40 fair agreement, 0.41 to 0.60 moderate agreement, 0.61 to 0.80 substantial agreement, and 0.81 to 1.00 almost perfect agreement. We studied the association between the four definitions of eGFR dichotomized at $60 \mathrm{~mL} / \mathrm{min} / 1.73 \mathrm{~m}^{2}$ in hypertensive and diabetic subjects by McNemar's test for paired comparisons of proportions. Because of the low frequencies in some cells, we applied exact statistics in two-by-two tables. Finally, we assessed the added capacity of $\mathrm{eGFR}_{\text {cys }}$ to differentiate between normotension versus hypertension or between people with or without diabetes mellitus, using the integrated discrimination improvement (IDI) and the net reclassification improvement (NRI) [22, 23]. Statistical significance was an $\alpha$ level of 0.05 .

\section{Results}

3.1. Characteristics of Participants. The 119 participants included 68 women (57.1\%) and 53 (44.5\%) hypertensive patients, of whom 35 (66.0\%) were on antihypertensive drug treatment. Among 68 women and 51 men, $11(16.2 \%)$ and $5(9.8 \%)$ were smokers; 21 women $(30.1 \%)$ and 32 men (62.7\%) reported intake of alcohol. In smokers, median tobacco use was 10 cigarettes per day (interquartile range, 6-15). In drinkers, the median alcohol consumption was $8 \mathrm{~g}$ per day (interquartile range, $4-54$ ). In the whole study population, age (SD) averaged was 56.5 (17.3) years and systolic and diastolic blood pressure 126.5 (19.6) $\mathrm{mm} \mathrm{Hg}$ and 79.6 (11.7) $\mathrm{mm} \mathrm{Hg}$, respectively. Based on a self-report of the main maternal and paternal background, 37 participants (31.1\%) reported a mixture of Caucasian, African, or NativeAmerican, while 82 participants (68.9\%) reported coincident Caucasian background.

Among all participants, serum cystatin $\mathrm{C}$ and serum creatinine averaged from $0.99(0.22) \mathrm{mg} / \mathrm{L}$ to $0.81(0.21)$ $\mathrm{mg} / \mathrm{dL}$ with no difference between women and men for cystatin C $(0.99$ versus $1.00 \mathrm{mg} / \mathrm{L} ; P=0.77)$, whereas women had lower serum creatinine than men had $(0.72$ versus $0.93 \mathrm{mg} / \mathrm{dL} ; P<0.0001)$. In all participants, mean values were $80.0(23.8) \mathrm{mL} / \mathrm{min} / 1.73 \mathrm{~m}^{2}$ for eGFR $\mathrm{eqs}, 89.7$ (22.5) $\mathrm{mL} / \mathrm{min} / 1.73 \mathrm{~m}^{2}$ for eGFR ${ }_{\mathrm{mdrd}}$, $91.5(19.0) \mathrm{mL} / \mathrm{min} /$ $1.73 \mathrm{~m}^{2}$ for $\mathrm{eGFR}_{\mathrm{epi}}$, and $85.6(20.2) \mathrm{mL} / \mathrm{min} / 1.73 \mathrm{~m}^{2}$ for $\mathrm{eGFR}_{\text {mix }}$, with no sex differences $(P \geq 0.23)$.

Table 1 provides the characteristics of participants by fourths of the distribution of $\mathrm{GGFR}_{\text {cys }}$, which was used as reference. The prevalence of hypertension $(P=0.027)$, age $(P<0.0001)$, and systolic blood pressure $(P=0.0097)$, but not diastolic blood pressure $(P=0.79)$ or mean arterial pressure $(P=0.18)$ increased $(P=0.027)$ with lower eGFR cys $_{\text {s }}$ category. The central systolic augmentation index and aortic pulse wave velocity also rose $(P<0.0001)$ across decreasing

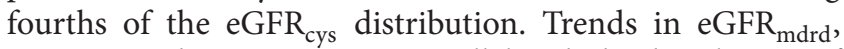
$\mathrm{eGFR}_{\text {epi }}$, and eGFR $\mathrm{mix}_{\text {r }}$ ran in parallel with the distribution of $\mathrm{eGFR}_{\text {cys }}$.

3.2. Concordance between Estimates of GFR on a Continuous Scale. Figure 1 shows the Bland and Altman plots comparing eGFR $\mathrm{mdrd}_{\mathrm{m}}$, $\mathrm{eGFR}_{\mathrm{epi}}$, and $\mathrm{GGFR}_{\text {mix }}$, with eGFR $\mathrm{Gys}_{\text {s }}$ as the referent method. Table 2 shows the mean deviations of $e G R_{\text {mdrd }}$, $e G F R_{\text {epi }}$, and $e G F R_{\text {mix }}$ from $e G F R_{\text {cys }}$. In all participants, eGFR mdrd,$e G F R_{\text {epi }}$, and $e G R_{\text {mix }}$ were, respectively, 9.7, 11.5 , and $5.6 \mathrm{~mL} / \mathrm{min} / 1.73 \mathrm{~m}^{2}$ higher than $\mathrm{eGFR}_{\text {cys }}$. The corresponding $\pm 2 \mathrm{SD}$ intervals expressed in $\mathrm{mL} / \mathrm{min} / 1.73 \mathrm{~m}^{2}$ (Figure 1) ranged from -38.5 to +57.9 for $\mathrm{eGFR}_{\mathrm{mdrd}},-25.5$ to +48.5 for $\mathrm{eGFR}$ epi , and -10.2 to +21.4 for $\mathrm{eGFR}_{\text {mix }}$, and the corresponding correlation coefficients were $-0.04(P=0.69),-0.26(P=0.0046)$, and $-0.40(P<$ $0.0001)$, respectively. Analyses stratified according to sex, age, normotension versus hypertension, and absence versus presence of diabetes mellitus were consistent with those in all participants (Table 2). Figure 2 shows that across fourths of the distribution of eGFR $\mathrm{cyy}_{\mathrm{s}}, \mathrm{eGFR}_{\text {mdrd }}, \mathrm{eGFR}_{\mathrm{epi}}$, and eGFR were consistently higher $(P<0.002)$ than eGFR cys $_{\text {except in }}$ the highest category of eGFR $\operatorname{cys}_{\text {c }}(P=0.25)$.

3.3. Concordance between Estimates of GFR on a Categorical Scale. The prevalence of L-GFR was the highest for eGFR ${ }_{c y s}$, 
TABLE 1: Characteristics of 119 participants by fourths of the distribution of eGFR cys $_{\text {s }}$

\begin{tabular}{|c|c|c|c|c|c|}
\hline \multirow{2}{*}{$\begin{array}{l}\text { Characteristic } \\
\mathrm{eGFR}_{\text {cys }} \text { limits, } \mathrm{mL} / \mathrm{min} / 1.73 \mathrm{~m}^{2}\end{array}$} & \multicolumn{4}{|c|}{ Categories of eGFR } & \multirow{2}{*}{$\begin{array}{c}P \\
\cdots\end{array}$} \\
\hline & $>93.7$ & $93.7-78.7$ & $78.7-61.5$ & $\leq 61.5$ & \\
\hline Number of subjects (\%) & 30 & 30 & 30 & 29 & $\cdots$ \\
\hline Women & $18(60.0)$ & $22(73.3)$ & $12(40.0)$ & $16(53.3)$ & 0.063 \\
\hline Smokers & $4(13.3)$ & $5(16.7)$ & $3(10.0)$ & $4(13.8)$ & 0.90 \\
\hline Drinking alcohol & $16(53.3)$ & $13(43.3)$ & $12(40.0)$ & $12(41.4)$ & 0.73 \\
\hline Hypertension & $8(26.7)$ & $11(36.7)$ & $16(53.3)$ & $18(62.1)$ & 0.027 \\
\hline Antihypertensive treatment & $3(10.0)$ & $8(26.7)$ & $12(40.0)$ & $12(66.6)$ & 0.32 \\
\hline Cardiovascular disease & $2(6.7)$ & $1(3.3)$ & $3(10.0)$ & $2(6.9)$ & 0.87 \\
\hline Diabetes mellitus & $4(13.3)$ & $1(3.3)$ & $7(23.3)^{*}$ & $8(27.6)$ & 0.058 \\
\hline \multicolumn{6}{|l|}{ Mean (SD) of characteristic } \\
\hline Age, years & $41.3(14.0)$ & $52.1(14.7)^{\dagger}$ & $64.2(13.9)^{\dagger}$ & $68.9(11.8)$ & $<0.0001$ \\
\hline Body mass index, $\mathrm{kg} / \mathrm{m}^{2}$ & $27.6(4.4)$ & $29.2(5.1)$ & $29.1(5.3)$ & $29.5(4.6)$ & 0.44 \\
\hline \multicolumn{6}{|l|}{ Office blood pressure } \\
\hline Systolic pressure, $\mathrm{mmHg}$ & $118.5(15.1)$ & $123.3(16.6)$ & $130.9(21.1)$ & $133.6(22.0)$ & 0.0097 \\
\hline Diastolic pressure, $\mathrm{mmHg}$ & $79.3(10.6)$ & $78.2(11.9)$ & $79.8(12.1)$ & $81.4(12.7)$ & 0.79 \\
\hline Pulse rate, beats per minute & $71.3(7.1)$ & $69.1(9.9)$ & $75.4(8.9)^{*}$ & $71.0(9.8)$ & 0.054 \\
\hline Central augmentation index, \% & $14.7(14.8)$ & $19.6(11.3)$ & $28.7(9.8)^{\dagger}$ & $23.6(10.9)$ & $<0.0001$ \\
\hline Aortic pulse wave velocity, m/s & $7.6(1.8)$ & $8.6(2.5)$ & $11.1(3.2)^{\dagger}$ & $10.0(2.9)$ & $<0.0001$ \\
\hline \multicolumn{6}{|l|}{ Biochemical measurements } \\
\hline Total cholesterol (mg/dL) & $204.2(30.2)$ & $194.6(28.8)$ & $216.5(38.6)^{*}$ & $225.3(34.9)$ & 0.004 \\
\hline Glucose (mg/dL) & $100.0(35.3)$ & $96.6(12.7)$ & $101.8(21.6)$ & $101.9(15.6)$ & 0.88 \\
\hline Serum cystatin C (mg/L) & $0.75(0.15)$ & $0.94(0.05)^{\S}$ & $1.03(0.07)^{\S}$ & $1.27(0.14)^{\S}$ & $<0.0001$ \\
\hline Serum creatinine, $\mathrm{mg} / \mathrm{dL}$ & $0.75(0.14)$ & $0.81(0.15)$ & $0.77(0.28)$ & $0.92(0.23)^{*}$ & 0.0077 \\
\hline $\mathrm{eGFR}_{\mathrm{mdrd}}, \mathrm{mL} / \mathrm{min} / 1.73 \mathrm{~m}^{2}$ & $103.2(21.6)$ & $92.9(16.1)^{*}$ & $90.1(24.5)$ & $71.9(5.4)^{\dagger}$ & $<0.0001$ \\
\hline $\mathrm{eGFR}_{\mathrm{epi}}, \mathrm{mL} / \mathrm{min} / 1.73 \mathrm{~m}^{2}$ & $107.1(14.2)$ & $96.4(12.8)^{\dagger}$ & $88.6(17.1)^{*}$ & $73.4(14.1)^{\ddagger}$ & $<0.0001$ \\
\hline $\mathrm{eGFR}_{\mathrm{mix}}, \mathrm{mL} / \mathrm{min} / 1.73 \mathrm{~m}^{2}$ & $110.4(13.1)$ & $90.7(7.0)^{\S}$ & $78.6(8.6)^{\S}$ & $61.8(9.2)^{\S}$ & $<0.0001$ \\
\hline
\end{tabular}

$\mathrm{eGFR}_{\mathrm{cys}}, \mathrm{eGFR}_{\mathrm{mdrd}}, \mathrm{eGFR}$ epi, and eGFR $\mathrm{mix}_{\text {ix }}$ indicate estimated glomerular filtration rate derived from serum cystatin $\mathrm{C}$, from serum creatinine according to the IDMS-traceable Modification of Diet in Renal Disease (MDRD) Study Equation or the Chronic Kidney Disease Epidemiology Collaboration equations, or from both serum cystatin $\mathrm{C}$ and creatinine. Office blood pressure was the average of five consecutive readings. Hypertension was an office blood pressure of $\geq 140 \mathrm{mmHg}$ systolic or $\geq 90 \mathrm{mmHg}$ diastolic or use of antihypertensive drugs. Diabetes mellitus was a fasting glucose level of $\geq 126 \mathrm{mg} / \mathrm{dL}$ or use of antidiabetic drugs. The central augmentation index was standardised to a heart rate of 75 beats/minute. Conversion factors: creatinine from $\mathrm{mg} / \mathrm{dL}$ to $\mu \mathrm{mol} / \mathrm{L}$, multiply by 88.4 ; cholesterol from $\mathrm{mg} / \mathrm{dL}$ to $\mathrm{mmol} / \mathrm{L}$, multiply by $0.0259 . P$ values denote the significance of the differences in prevalence or means across quartiles of $\mathrm{eGFR}_{\text {cys }}$. Significance of the difference with the adjacent lower fourth: ${ }^{*} P \leq 0.05 ;{ }^{\dagger} P \leq 0.01 ;{ }^{\ddagger} P \leq 0.001 ;{ }^{\circledR} P \leq 0.0001$.

intermediate for $\mathrm{eGFR}_{\text {mix }}$, and the lowest for $\mathrm{eGFR}$ mdrd and eGFR $_{\text {epi }}$ (Table 3). Using eGFR cys $_{\text {s }}$ as reference, Cohen's kappa statistic was 0.230 (95\% confidence interval [CI], 0.036 to 0.427; $P=0.0005)$ for $\mathrm{eGFR}_{\mathrm{mdrd}}, 0.151$ (CI, -0.021 to 0.322 ; $P=0.032$ ) for $\mathrm{eGFR}_{\mathrm{epi}}$, and 0.587 (CI, 0.399 to $0.775 ; P<$ 0.0001 ) for eGFR ${ }_{\text {mix }}$.

\subsection{Association between Chronic Kidney Disease and Response} Variables. Among 53 hypertensive patients, the prevalence of L-GFR was higher $(P<0.0001)$ if patients were categorized based on eGFR $\mathrm{Cys}_{\text {ch }}$ (17 patients, 32.1\%) compared with $\mathrm{eGFR}_{\text {mdrd }}$ (4 patients, 7.5\%), eGFR epi (3 patients, $5.7 \%$ ), or $\mathrm{eGFR}_{\text {mix }}$ (8 patients, 15.1\%). Among 20 diabetic patients, we observed a similar trend. The prevalence of L-GFR was 8 patients $(40.0 \%)$ based on eGFR cys, 2 patients $(10.0 \%)$ based on $\mathrm{eGFR}_{\mathrm{mdrd}}, 2$ patients $(10.0 \%)$ based on $\mathrm{eGFR}_{\text {epi }}$, and 3 patients $(15 \%)$ based on $\mathrm{eGFR}_{\mathrm{mix}}$. However, the differences with eGFR cys $_{\text {did not reach formal statistical significance }(P \geq} \geq$ 0.075).

Finally, we explored whether an eGFR $_{\text {cys }}$ below $60 \mathrm{~mL} /$ $\mathrm{min} / 1.73 \mathrm{~m}^{2}$ improved the differentiation between normotension versus hypertension or between people without or with diabetes mellitus based on the other estimates of GFR. However, the classification based on $\mathrm{eGFR}_{\text {cys }}$ did not improve IDI $(P \geq 0.53)$ or NRI $(P \geq 0.24)$ for hypertension or IDI $(P \geq 0.37)$ or NRI $(P \geq 0.24)$ for diabetes mellitus.

\section{Discussion}

In our current analysis, we compared the performance of the equations based on cystatin $\mathrm{C}$ and creatinine to estimate GFR in a Uruguayan population sample. The Uruguayan population has been considered as mainly European descent, with a negligible Native American or African contributions. 


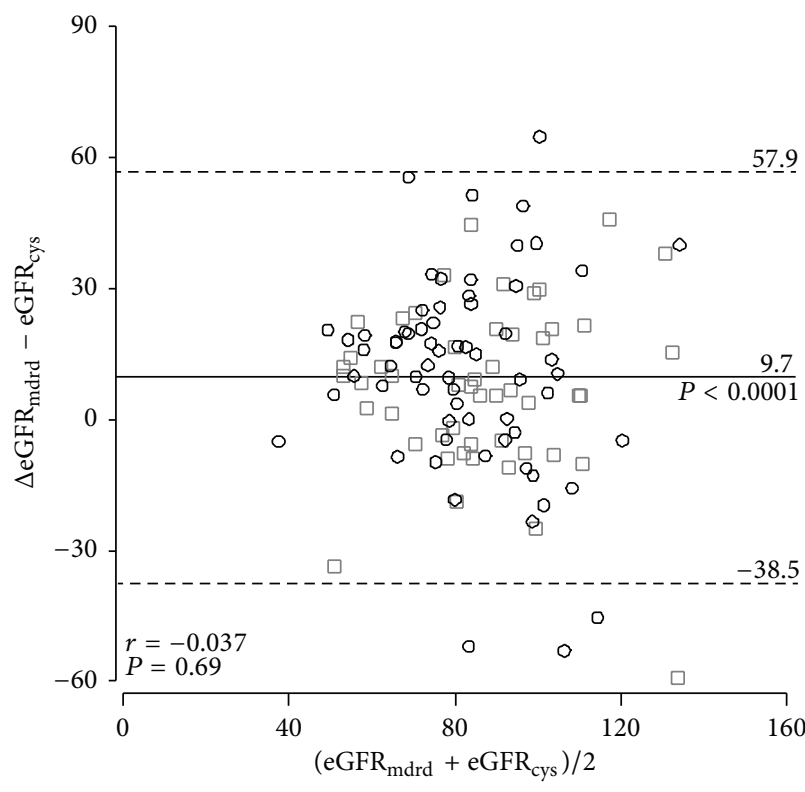

(a)

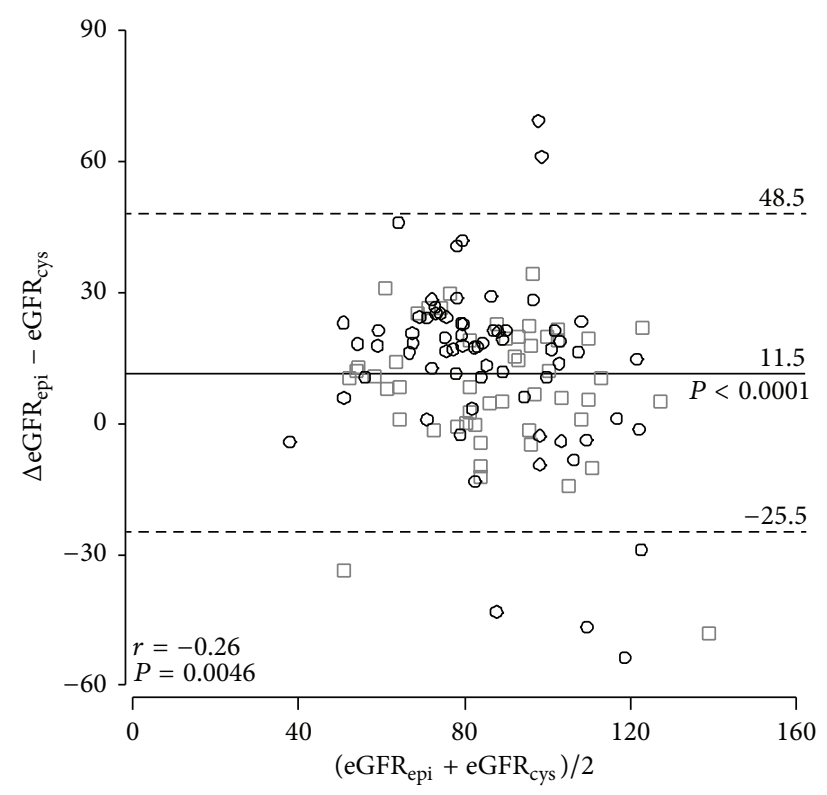

(b)

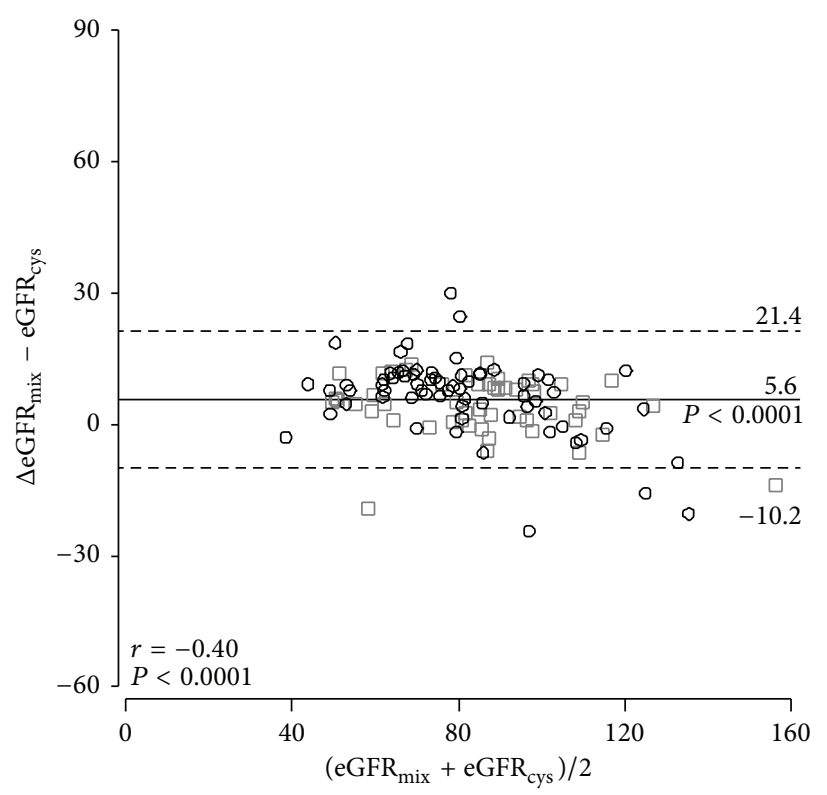

(c)

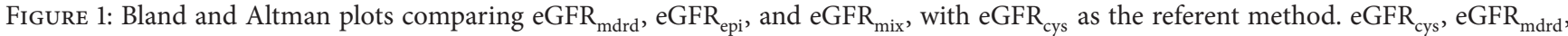
$\mathrm{eGFR}_{\mathrm{epi}}$, and $\mathrm{eGFR}_{\text {mix }}$ indicate estimated glomerular filtration rate derived from serum cystatin $\mathrm{C}$, from serum creatinine according to the Modification of Diet in Renal Disease or the Chronic Kidney Disease Epidemiology Collaboration equations, or from both serum cystatin C and creatinine. $R$ indicate the intraclass correlation coefficient. $P$ denotes the significance level.

However, based on serological and molecular markers, recent studies demonstrate that Native American and African had an important influence in the conformation of the present one [24-26].

The key finding was that $\mathrm{eGFR}_{\text {cys }}$ provides lower estimates in comparison with creatinine based equations $\left(\mathrm{eGFR}_{\mathrm{mdrd}}\right.$ and $\left.\mathrm{eGFR}_{\mathrm{epi}}\right)$. Mean eGFR was 80.0 , 89.7, 91.5, and $85.6 \mathrm{~mL} / \mathrm{min} / 1.73 \mathrm{~m}^{2}$ for eGFR $\mathrm{cys}_{\text {s }}$, eGFR $\mathrm{mdrd}_{\text {, }}$ eGFR $\mathrm{epi}_{\text {, }}$, and $\mathrm{eGFR}_{\text {mix }}$, respectively. Thus, the prevalence of L-GFR, was higher when derived from equations involving cystatin
$\mathrm{C}\left(\mathrm{eGFR}_{\text {cys }}\right.$ and $\mathrm{eGFR}$ mix $)$ than when derived from creatinine based equations. The prevalence of L-GFR using $\mathrm{eGFR}_{\text {cys' }}$, $\mathrm{eGFR}_{\text {mdrd }}$, eGFR $\mathrm{epi}_{\text {, and }} \mathrm{eGFR}_{\text {mix }}$ was $21.8 \%, 5.9 \%, 3.4 \%$, and $11.8 \%$, respectively. In categorical analysis, the agreement between cystatin-based ( $\mathrm{eGFR}_{\text {cys }}$ ) equations and creatininebased equations $\left(e G F R_{\text {mdrd }}\right.$ and $e \mathrm{GFR}_{\text {epi }}$ ) to detect eGFR under $60 \mathrm{~mL} / \mathrm{min} / 1.73 \mathrm{~m}^{2}$ was low.

Over the past, many reports highlighted the ability of cystatin $\mathrm{C}$ to detect renal disease early in different settings [27-31]. Several researchers reported cystatin C outperforms 
TABLE 2: Differences between various estimates of GFR with eGFR derived from serum cystatin C as referent method.

\begin{tabular}{|c|c|c|c|c|}
\hline \multirow{2}{*}{ Group } & \multirow{2}{*}{$N$} & \multicolumn{3}{|c|}{ Difference in estimates of glomerular filtration rate $\left(\mathrm{mL} / \mathrm{min} / 1.73 \mathrm{~m}^{2}\right)$} \\
\hline & & $\mathrm{eGFR}_{\mathrm{mdrd}}$ & $\mathrm{eGFR}_{\mathrm{epi}}$ & $\mathrm{eGFR}_{\text {mix }}$ \\
\hline All participants & 119 & $9.7(5.3-14.0)^{\S}$ & $11.5(8.2-14.9)^{\S}$ & $5.6(4.1-7.0)^{\S}$ \\
\hline Women & 68 & $11.3(4.7-17.9)^{\ddagger}$ & $13.7(8.7-18.6)^{\S}$ & $6.4(4.3-8.5)^{\S}$ \\
\hline Men & 51 & $7.5(2.1-12.9)^{\S}$ & $8.7(4.3-12.9)^{\ddagger}$ & $4.5(2.6-6.3)^{\S}$ \\
\hline$<60$ years & 57 & $3.2(-4.1-10.4)$ & $9.6(3.9-15.3)^{\dagger}$ & $4.5(2.1-6.8)^{\ddagger}$ \\
\hline$\geq 60$ years & 62 & $15.6(10.8-20.5)^{\S}$ & $13.3(9.4-17.2)^{\S}$ & $6.6(4.9-8.3)^{\S}$ \\
\hline Normotension & 66 & $8.1(0.9-15.3)^{*}$ & $10.4(4.9-15.8)^{\ddagger}$ & $4.9(2.6-7.3)^{\S}$ \\
\hline Hypertension & 53 & $11.6(7.3-15.9)^{\S}$ & $12.9(9.5-16.4)^{\S}$ & $6.3(4.8-7.7)^{\S}$ \\
\hline No diabetes & 99 & $9.5(4.7-14.4)^{\ddagger}$ & $11.9(8.3-15.7)^{\S}$ & $5.7(4.1-7.3)^{\S}$ \\
\hline Diabetes & 20 & $10.3(-0.7-21.3)$ & $9.4(0.7-18.1)^{*}$ & $4.9(1.4-8.4)^{\dagger}$ \\
\hline
\end{tabular}

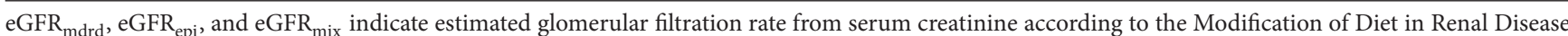
or the Chronic Kidney Disease Epidemiology Collaboration equations or from both serum cystatin C and creatinine. Differences were computed as eGFR $\mathrm{mdrd}_{\mathrm{m}}$,

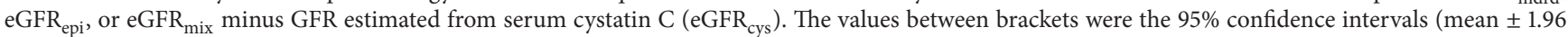
standard errors). $N$ indicates the number of participants. Significance of the difference with eGFR cys $^{*}{ }^{*} P \leq 0.05 ;{ }^{\dagger} P \leq 0.01 ;{ }^{\ddagger} P \leq 0.001 ;{ }^{\S} P \leq 0.0001$.

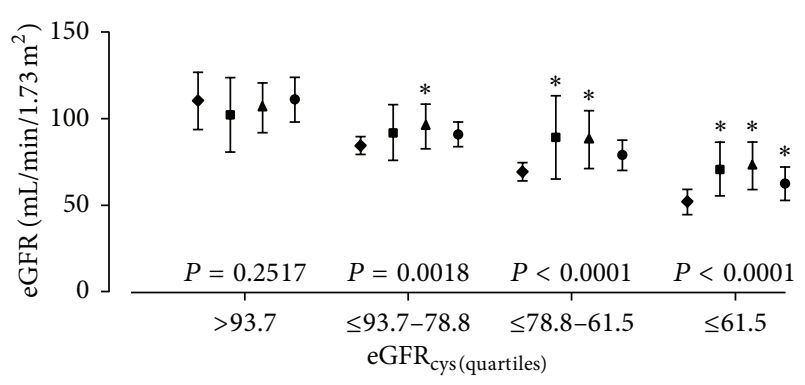

Figure 2: Mean and mean \pm 1 standard deviation interval of eGFR $(\bullet), \mathrm{eGFR}_{\text {mdrd }}(\boldsymbol{\bullet}), \mathrm{eGFR}_{\mathrm{epi}}(\boldsymbol{\Delta})$, and $\mathrm{eGFR}_{\text {mix }}(\bullet)$ across fourths of the distribution of eGFR ${ }_{\text {cys }}$. The abbreviations eGFR ${ }_{\text {cys }}, \mathrm{eGFR}_{\mathrm{mdrd}}$, $\mathrm{eGFR}_{\text {epi }}$, and $\mathrm{GGFR}_{\text {mix }}$ indicate estimated glomerular filtration rate derived from serum cystatin $\mathrm{C}$, from serum creatinine according to the Modification of Diet in Renal Disease or the Chronic Kidney Disease Epidemiology Collaboration equations, or from both serum cystatin $\mathrm{C}$ and creatinine. $\mathrm{eGFR}_{\text {mdrd }}, \mathrm{eGFR}_{\text {epi }}$, and $\mathrm{eGFR}_{\text {mix }}$ were consistently higher $(P<0.0001)$ than eGFR $_{\text {cys }}$ except in the highest category of $\mathrm{eGFR}_{\text {cys }}(P=0.25)$.

serum creatinine in the early diagnosis of acute kidney injury $[32,33]$ or its prognosis [34]. In line with our results, other investigators reported lower estimates of eGFR using cystatin $\mathrm{C}$ as biomarker $[6,35,36]$. In contrast, in a Belgian population sample $[n=4,189]$, Delanaye and colleagues report that the prevalence of eGFR below $60 \mathrm{~mL} / \mathrm{min} / 1.73 \mathrm{~m}^{2}$ using eGFR ${ }_{\text {cys }}$, $\mathrm{eGFR}_{\text {mdrd }}$, eGFR epi , and eGFR mix $_{\text {mas }} 4.7 \%, 13.0 \%, 9.8 \%$, and $5.0 \%$, respectively [37]. In a recent report, among 394 old $(>74 \mathrm{y})$ subjects and patients from England, Kilbride and colleagues describe lower $\operatorname{eGFR}_{\text {cys }}\left(55.2 \mathrm{~mL} / \mathrm{min} / 1.73 \mathrm{~m}^{2}\right)$ in comparison with creatinine based equations $\left(\mathrm{eGFR}_{\mathrm{mdrd}}\right.$, $57.6 \mathrm{~mL} / \mathrm{min} / 1.73 \mathrm{~m}^{2}$; $\mathrm{eGFR}_{\text {epi }}, 57.0 \mathrm{~mL} / \mathrm{min} / 1.73 \mathrm{~m}^{2}$ ) [38]. Grams and colleagues [36], analyzing representative subsamples of the adult participants in the National Health and Nutrition Examination Surveys (NHANES; 1988-1994 [ $n=$ $15,133]$ and 1999-2002 [ $n=8,238])$, observed slightly higher eGFR using cystatin $\mathrm{C}$ than creatinine equations (102.9 versus
$99.4 \mathrm{~mL} / \mathrm{min} / 1.73 \mathrm{~m}^{2}$ ). However, in line with our results, the proportion of subjects with eGFR below $60 \mathrm{~mL} / \mathrm{min} / 1.73 \mathrm{~m}^{2}$ was larger if derived from cystatin $\mathrm{C}$ than creatinine $(5.5 \%$ versus $4.7 \%$ ). More recently, Tsai and colleagues [35] reported similar results in diabetic patients enrolled in NHANES. The mean $\mathrm{eGFR}_{\text {cys }}$ was $100.7 \mathrm{~mL} / \mathrm{min} / 1.73 \mathrm{~m}^{2}$ and the $\mathrm{eGFR}_{\text {epi }}$ was $95.1 \mathrm{~mL} / \mathrm{min} / 1.73 \mathrm{~m}^{2}$ while the proportions of patients with eGFR below $60 \mathrm{~mL} / \mathrm{min} / 1.73 \mathrm{~m}^{2}$ were $22.0 \%$ and $16.5 \%$, respectively. Pattaro and colleagues also found similar results in a cross-sectional analysis of a population from three alpine villages [39]. Finally, in a recent meta-analysis Shlipak and colleagues noticed similar mean eGFR $\mathrm{cys}_{\text {s }}$ and eGFR $\mathrm{epi}$ estimates while the proportion of subjects under the threshold to define CKD was 13.7 and $9.7 \mathrm{~mL} / \mathrm{min} / 1.73 \mathrm{~m}^{2}$ using cystatin and creatinine based equations, respectively [6].

In line with our current results, Delanaye described low agreement between creatinine and cystatin $\mathrm{C}$ based formulas (kappa statistic 0.32 [eGFR $_{\text {cys }}$ versus $\mathrm{eGFR}_{\mathrm{mdrd}}$ ] and 0.39 [eGFR cys $_{\text {versus }} \mathrm{eGFR}_{\text {epi }}$ ]) [37]. In this Belgian study, the percentage of discordant subjects estimated by $\mathrm{eGFR}_{\mathrm{mdrd}}$, $\mathrm{eGFR}_{\text {epi }}$, and $\mathrm{eGFR}_{\text {mix }}$ was $11.2 \%, 8.29 \%$, and $2.71 \%$, taking $\mathrm{eGFR}_{\text {cys }}$ as reference.

How to explain the discrepancies between cystatin $\mathrm{C}$ and creatinine based equations? We first discarded all potential sources of preanalytical and analytical errors. We analysed creatinine in fresh serum samples and cystatin $C$ in samples that were kept frozen at $-80^{\circ} \mathrm{C}$. Over a period of 10 years, a decay in cystatin $\mathrm{C}$ levels occurs using a particleenhanced nephelometric assay (PENIA) [40]. Such decay is not observed if one uses the more robust particle-enhanced turbidimetric assay (PETIA). Furthermore, our samples were analysed within one year after blood collection and were processed with calibration each time. We used a validated method [40, 41] and reagents (Tina-quant Cystatin C Gen. 2) standardized to the international reference material ERMDA 471/IFCC, as currently recommended for the use of CKDEPI equations [3, 7]. Studies of bias (mean difference from reference method) usually overestimated GFR compared 
TABLE 3: Prevalence by categories of eGFR according to the stages of chronic kidney disease, for equation to estimate the GFR.

\begin{tabular}{|c|c|c|c|c|c|}
\hline \multirow{2}{*}{ Stage of kidney disease } & \multicolumn{4}{|c|}{ Estimated glomerular filtration rate } & \multirow{2}{*}{$P$} \\
\hline & $\mathrm{eGFR}_{\text {cys }}$ & $\mathrm{eGFR}_{\mathrm{mdrd}}$ & $\mathrm{eGFR}_{\mathrm{epi}}$ & $\mathrm{eGFR}_{\text {mix }}$ & \\
\hline$<60 \mathrm{~mL} / \mathrm{min} / 1.73 \mathrm{~m}^{2}$ & $26(21.8)$ & $7(5.9)^{\ddagger}$ & $4(3.4)^{\S}$ & $14(11.8)^{*}$ & $<0.0001$ \\
\hline $60-89 \mathrm{~mL} / \mathrm{min} / 1.73 \mathrm{~m}^{2}$ & $56(47.1)$ & $59(49.6)$ & $51(42.8)$ & $58(48.7)$ & 0.73 \\
\hline$\geq 90 \mathrm{~mL} / \mathrm{min} / 1.73 \mathrm{~m}^{2}$ & $37(31.1)$ & $53(44.5)^{*}$ & $64(53.8)^{\ddagger}$ & $47(39.5)$ & 0.004 \\
\hline
\end{tabular}

$\mathrm{eGFR}_{\text {cys }}, \mathrm{eGFR}_{\mathrm{mdrd}}$, eGFR $\mathrm{epi}_{\text {, and }}$ eGFR $\mathrm{mix}_{\text {ix }}$ indicate estimated glomerular filtration rate derived from serum cystatin $\mathrm{C}$, from serum creatinine according to the Modification of Diet in Renal Disease or the Chronic Kidney Disease Epidemiology Collaboration equations or from both serum cystatin C and creatinine. Values are number of participants (\%). $P$ values are for the overall difference across four estimates of glomerular filtration rate. Significance of the difference with eGFR ${ }_{\text {cys }}:{ }^{*} P \leq 0.05 ;{ }^{\dagger} P \leq 0.01 ;{ }^{\ddagger} P \leq 0.001 ;{ }^{\S} P \leq 0.0001$.

with the reference when using MDRD (range -1.0 to +3.5 ) or CKD-EPI (range -0.23 to +4.4 ) and underestimated when using cystatin $\mathrm{C}$ based equations (range -5.7 to -1.2 ) $[38,42-$ 44]. Fewer studies showed a lower positive bias of cystatin C than CKD-EPI based equations [7, 45].

Several epidemiological studies showed that cystatin C is a better predictor of outcomes in coronary heart disease, acute coronary syndrome, and heart failure, independently of serum creatinine and GFR estimation [6, 46-49]. Furthermore, Peralta et al. demonstrated in a large and ethnically diverse population that subjects with decreased eGFR $\mathrm{Cys}_{\text {ch }}$ had elevated risk of death, cardiovascular disease, and heart failure and had an elevated risk of kidney failure [50, 51]. In keeping with these studies, our population sample had a high cardiovascular risk profile. We found a higher prevalence of L-GFR among hypertensive subjects $(P<0.001)$ if they were categorized based on eGFR $\mathrm{Gys}_{\text {c }}(32.1 \%)$ than on eGFR (5.7\%) with a similar but not significant trend among the few diabetics patients. However, when computing IDI and NRI we did not observe significant differences between the various estimates of eGFR for hypertension or diabetes $(P \geq$ $0.24)$. In accordance with previous reports $[48,52-54]$, the prevalence of hypertension $(P=0.27)$ and age $(P<0.0001)$, systolic blood pressure $(P<0.01)$, cholesterol $(P=0.004)$, aortic pulse wave velocity $(P<0.0001)$, and the central augmentation index $(P<0.0001)$ increased with lower categories of $\mathrm{eGFR}_{\mathrm{cys}}$ (Table 1$)$.

Our results should be interpreted within the limitation of the study. First, we did not have a reliable "gold standard" due to the variability in $24 \mathrm{~h}$ urine collections. Performing inulin or iothalamate clearance implies invasive and tedious procedures that are not suitable for our population study. Second, participants of the study may not be representative of the Uruguayan population, because we randomly sampled a neighbourhood and our participants had a higher cardiovascular risk profile than the general population of Uruguay [55]. Finally, the small sample size of our population is a limiting factor to analyse specific subgroups of participants. However, the number of participants is large enough to describe the difference between eGFR estimating equations.

In conclusion, to our knowledge, this is the first report based on a population from South America comparing to the performance of eGFR equations based on cystatin $\mathrm{C}$ and creatinine. We confirm discrepancies in eGFR using equation based on different biomarkers, particularly in the range of GFR under $60 \mathrm{~mL} / \mathrm{min} / 1.73 \mathrm{~m}^{2}$. Generally, the equation based on cystatin C, compared with creatinine, results in lower eGFR values and, therefore, higher estimates of the prevalence of eGFR below $60 \mathrm{~mL} / \mathrm{min} / 1.73 \mathrm{~m}^{2}$.

\section{Conflict of Interests}

The authors declare that there is no conflict of interests regarding the publication of this paper.

\section{Acknowledgments}

The authors gratefully acknowledge Mrs. Verónika Larraura (Unidad de Hipertensión Arterial, Montevideo) and Mrs. Annick De Soete (Studies Coordinating Centre, Leuven) for expert clerical assistance. They thank the community leaders and the participants of the Juana de América neighbourhood for their collaboration in the fieldwork. The Comisión Sectorial de Investigación Científica, Universidad de la República (grant I + D 2010), and the Agencia Nacional de Investigación e Innovación (grant FMV 2-20111-6414) gave support to GEFA-HT-UY. The European Union (Grants IC15-CT98-0329-EPOGH, LSHM-CT-2006-037093InGenious HyperCare, HEALTH-2007-2.1.1-2-HyperGenes, HEALTH-2011.2.4.2-2-EU-MASCARA, and HEALTH-F7305507 HOMAGE and the European Research Council Advanced Researcher Grant-2011-294713-EPLORE) and the Ministry of the Flemish Community, Brussels, Belgium (Grants G.0880.13 and G.0881.13) supported the Studies Coordinating Centre, Leuven, Belgium.

\section{References}

[1] A. S. Levey, J. P. Bosch, J. B. Lewis, T. Greene, N. Rogers, and D. Roth, "A more accurate method to estimate glomerular filtration rate from serum creatinine: a new prediction equation," Annals of Internal Medicine, vol. 130, no. 6, pp. 461-470, 1999.

[2] A. S. Levey, L. A. Stevens, C. H. Schmid et al., "A new equation to estimate glomerular filtration rate," Annals of Internal Medicine, vol. 150, no. 9, pp. 604-612, 2009.

[3] L. A. Inker, C. H. Schmid, H. Tighiouart et al., "Estimating glomerular filtration rate from serum creatinine and cystatin C," New England Journal of Medicine, vol. 367, no. 1, pp. 20-29, 2012.

[4] J. Kyhse-Andersen, C. Schmidt, G. Nordin et al., "Serum cystatin $\mathrm{C}$, determined by a rapid, automated particle-enhanced turbidimetric method, is a better marker than serum creatinine 
for glomerular filtration rate," Clinical Chemistry, vol. 40, no. 10, pp. 1921-1926, 1994.

[5] E. Premaratne, R. J. MacIsaac, S. Finch, S. Panagiotopoulos, E. Ekinci, and G. Jerums, "Serial measurements of cystatin c are more accurate than creatinine-based methods in detecting declining renal function in type 1 diabetes," Diabetes Care, vol. 31, no. 5, pp. 971-973, 2008.

[6] M. G. Shlipak, K. Matsushita, J. Ärnlöv et al., "Cystatin C versus creatinine in determining risk based on kidney function," The New England Journal of Medicine, vol. 369, pp. 932-943, 2013.

[7] L. Fan, L. A. Inker, J. Rossert et al., "Glomerular filtration rate estimation using cystatin $\mathrm{C}$ alone or combined with creatinine as a confirmatory test," Nephrology Dialysis Transplantation, vol. 29, no. 6, pp. 1195-1203, 2014.

[8] L. Luzardo, I. Lujambio, M. Sottolano et al., "Cohorte GEFAHT-UY (GEnotipo, Fenotipo y Ambiente de la HiperTensión Arterial en UruguaY)," Revista Médica del Uruguay, vol. 29, pp. 103-113, 2013.

[9] L. M. Van Bortel, E. J. Balkestein, J. J. van der HeijdenSpek et al., "Non-invasive assessment of local arterial pulse pressure: comparison of applanation tonometry and echotracking," Journal of Hypertension, vol. 19, no. 6, pp. 1037-1044, 2001.

[10] C. H. Chen, E. Nevo, B. Fetics et al., "Estimation of Central aortic pressure waveform by mathematical transformation of radial tonometry pressure: validation of generalized transfer function," Circulation, vol. 95, no. 7, pp. 1827-1836, 1997.

[11] A. L. Pauca, M. F. O'Rourke, and N. D. Kon, "Prospective evaluation of a method for estimating ascending aortic pressure from the radial artery pressure waveform," Hypertension, vol. 38, no. 4, pp. 932-937, 2001.

[12] L. M. van Bortel, S. Laurent, P. Boutouyrie et al., "Expert consensus document on the measurement of aortic stiffness in daily practice using carotid-femoral pulse wave velocity," Journal of Hypertension, vol. 30, no. 3, pp. 445-448, 2012.

[13] L. D. Bowers and E. T. Wong, "Kinetic serum creatinine assays. II. A critical evaluation and review," Clinical Chemistry, vol. 26, no. 5, pp. 555-561, 1980.

[14] M. Peake and M. Whiting, "Measurement of serum creatininecurrent status and future goals," The Clinical Biochemist Reviews, vol. 27, no. 4, pp. 173-182, 2006.

[15] G. L. Myers, W. G. Miller, J. Coresh et al., "Recommendations for improving serum creatinine measurement: a report from the Laboratory Working Group of the National Kidney Disease Education Program," Clinical Chemistry, vol. 52, no. 1, pp. 5-18, 2006.

[16] "Laboratory evaluation-Creatinine Standardization Recommendations," Internet source, http://nkdep.nih.gov/.

[17] A. S. Levey, J. Coresh, T. Greene et al., "Expressing the modification of diet in renal disease study equation for estimating glomerular filtration rate with standardized serum creatinine values," Clinical Chemistry, vol. 53, no. 4, pp. 766-772, 2007.

[18] A. S. Levey, J. Coresh, T. Greene, L. A. Stevens, Y. Zhang, and S. Hendriksen, "Chronic Kidney Disease Epidemiology Collaboration. Using standardized serum creatinine values in the Modification of Diet in Renal Disease study equation for estimating glomerular filtration rate (Annals of Internal Medicine (2006) 145, (247-254))," Annals of Internal Medicine, vol. 145, pp. 247-254, 2008.

[19] J. M. Bland and D. G. Altman, "Statistical methods for assessing agreement between two methods of clinical measurement," The Lancet, vol. 1, no. 8476, pp. 307-310, 1986.
[20] KDOQI Guidelines, http://www.kidney.org/.

[21] J. R. Landis and G. G. Koch, "The measurement of observer agreement for categorical data," Biometrics, vol. 33, no. 1, pp. 159-174, 1977.

[22] M. J. Pencina, S. D'Agostino, R. B. D'Agostino, and R. S. Vasan, "Evaluating the added predictive ability of a new marker: from area under the ROC curve to reclassification and beyond," Statistics in Medicine, vol. 27, no. 2, pp. 157-172, 2008.

[23] M. J. Pencina, R. B. D’Agostino Sr., and E. W. Steyerberg, "Extensions of net reclassification improvement calculations to measure usefulness of new biomarkers," Statistics in Medicine, vol. 30, no. 1, pp. 11-21, 2011.

[24] B. Bertoni, L. Jin, R. Chakraborty, and M. Sans, "Directional mating and a rapid male population expansion in a hybrid Uruguayan population," American Journal of Human Biology, vol. 17, no. 6, pp. 801-808, 2005.

[25] C. Gascue, A. Mimbacas, M. Sans et al., "Frequencies of the four major Amerindian mtDNA haplogroups in the population of Montevideo, Uruguay," Human Biology, vol. 77, no. 6, pp. 873878, 2005.

[26] M. Sans, "Race', ethnic and genetic adscription in Uruguay," Runa, vol. 30, no. 2, pp. 163-174, 2009.

[27] V. R. Dharnidharka, C. Kwon, and G. Stevens, "Serum cystatin C is superior to serum creatinine as a marker of kidney function: a meta-analysis," American Journal of Kidney Diseases, vol. 40, no. 2, pp. 221-226, 2002.

[28] E. Coll, A. Botey, L. Alvarez et al., "Serum cystatin C as a new marker for noninvasive estimation of glomerular filtration rate and as a marker for early renal impairment," American Journal of Kidney Diseases, vol. 36, no. 1, pp. 29-34, 2000.

[29] H. Mangge, P. Liebmann, H. Tanil et al., "Cystatin C, an early indicator for incipient renal disease in rheumatoid arthritis," Clinica Chimica Acta, vol. 300, no. 1-2, pp. 195-202, 2000.

[30] L. Pucci, S. Triscornia, D. Lucchesi et al., "Cystatin C and estimates of renal function: searching for a better measure of kidney function in diabetic patients," Clinical Chemistry, vol. 53, no. 3, pp. 480-488, 2007.

[31] K. Nitta, T. Hayashi, K. Uchida et al., "Serum cystatin C concentration as a marker of glomerular filtration rate in patients with various renal diseases," Internal Medicine, vol. 41, no. 11, pp. 931-935, 2002.

[32] K. Soto, S. Coelho, B. Rodrigues et al., "Cystatin C as a marker of acute kidney injury in the emergency department," Clinical Journal of the American Society of Nephrology, vol. 5, no. 10, pp. 1745-1754, 2010.

[33] Z. Zhang, B. Lu, X. Sheng, and N. Jin, "Cystatin C in prediction of acute kidney injury: a systemic review and meta-analysis," American Journal of Kidney Diseases, vol. 58, no. 3, pp. 356-365, 2011.

[34] A. Spahillari, C. R. Parikh, K. Sint et al., "Serum cystatin C- versus creatinine-based definitions of acute kidney injury following cardiac surgery: a prospective cohort study," The American Journal of Kidney Diseases, vol. 60, no. 6, pp. 922-929, 2012.

[35] C. W. Tsai, M. E. Grams, L. A. Inker, J. Coresh, and E. Selvin, "Cystatin C- and creatinine-based estimated glomerular filtration rate, vascular disease, and mortality in persons with diabetes in the U.S.," Diabetes Care, vol. 37, no. 4, pp. 1002-1008, 2014.

[36] M. E. Grams, S. P. Juraschek, E. Selvin et al., "Trends in the prevalence of reduced GFR in the United States: a comparison 
of creatinine- and cystatin c-based estimates," American Journal of Kidney Diseases, vol. 62, no. 2, pp. 253-260, 2013.

[37] P. Delanaye, E. Cavalier, O. Moranne, L. Lutteri, J. Krzesinski, and $\mathrm{O}$. Bruyère, "Creatinine-or cystatin C-based equations to estimate glomerular filtration in the general population: impact on the epidemiology of chronic kidney disease," $B M C$ Nephrology, vol. 14, no. 1, article 57, 2013.

[38] H. S. Kilbride, P. E. Stevens, G. Eaglestone et al., "Accuracy of the MDRD (Modification of Diet in Renal Disease) study and CKD-EPI (CKD Epidemiology Collaboration) equations for estimation of GFR in the elderly," American Journal of Kidney Diseases, vol. 61, no. 1, pp. 57-66, 2013.

[39] C. Pattaro, P. Riegler, G. Stifter, M. Modenese, C. Minelli, and P. P. Pramstaller, "Estimating the glomerular filtration rate in the general population using different equations: effects on classification and association," Nephron-Clinical Practice, vol. 123, no. 1-2, pp. 102-111, 2013.

[40] N. V. Voskoboev, T. S. Larson, A. D. Rule, and J. C. Lieske, "Analytic and clinical validation of a standardized cystatin C particle enhanced turbidimetric assay (PETIA) to estimate glomerular filtration rate," Clinical Chemistry and Laboratory Medicine, vol. 50, no. 9, pp. 1591-1596, 2012.

[41] M. Conde-Sánchez, E. Roldán-Fontana, N. Chueca-Porcuna, S. Pardo, and J. Porras-Gracia, "Analytical performance evaluation of a particle-enhanced turbidimetric cystatin $\mathrm{C}$ assay on the Roche COBAS 6000 analyzer," Clinical Biochemistry, vol. 43, no. 10-11, pp. 921-925, 2010.

[42] L. A. Stevens, C. H. Schmid, T. Greene et al., "Comparative performance of the CKD Epidemiology Collaboration (CKD-EPI) and the Modification of Diet in Renal Disease (MDRD) Study equations for estimating GFR levels above $60 \mathrm{~mL} / \mathrm{min} / 1.73 \mathrm{~m} 2$," American Journal of Kidney Diseases, vol. 56, no. 3, pp. 486-495, 2010.

[43] I. Masson, N. Maillard, I. Tack et al., "GFR estimation using standardized cystatin C in kidney transplant recipients," American Journal of Kidney Diseases, vol. 61, no. 2, pp. 279-284, 2013.

[44] J.-F. Feng, L. Qiu, L. Zhang et al., "Multicenter study of creatinine- and/or cystatin C-based equations for estimation of glomerular filtration rates in Chinese patients with chronic kidney disease," PLoS ONE, vol. 8, no. 3, Article ID e57240, 2013.

[45] M. Zhang, Y. Chen, L. Tang et al., "Applicability of chronic kidney disease epidemiology collaboration equations in a Chinese population," Nephrology, Dialysis, Transplantation, vol. 29, no. 3, pp. 580-586, 2014.

[46] M. G. Shlipak, R. Katz, M. J. Sarnak et al., "Cystatin C and prognosis for cardiovascular and kidney outcomes in elderly persons without chronic kidney disease," Annals of Internal Medicine, vol. 145, no. 4, pp. 237-246, 2006.

[47] M. G. Shlipak, M. J. Sarnak, R. Katz et al., "Cystatin C and the risk of death and cardiovascular events among elderly persons," The New England Journal of Medicine, vol. 352, no. 20, pp. 20492060, 2005.

[48] W. Koenig, D. Twardella, H. Brenner, and D. Rothenbacher, "Plasma concentrations of cystatin $\mathrm{C}$ in patients with coronary heart disease and risk for secondary cardiovascular events: more than simply a marker of glomerular filtration rate," Clinical Chemistry, vol. 51, no. 2, pp. 321-327, 2005.

[49] T. Jernberg, B. Lindahl, S. James, A. Larsson, L.-O. Hansson, and L. Wallentin, "Cystatin C: a novel predictor of outcome in suspected or confirmed non-ST-elevation acute coronary syndrome," Circulation, vol. 110, no. 16, pp. 2342-2348, 2004.
[50] C. A. Peralta, R. Katz, M. J. Sarnak et al., "Cystatin C identifies chronic kidney disease patients at higher risk for complications," Journal of the American Society of Nephrology, vol. 22, no. 1, pp. 147-155, 2011.

[51] C. A. Peralta, M. G. Shlipak, S. Judd et al., "Detection of chronic kidney disease with creatinine, cystatin $\mathrm{C}$, and urine albuminto-creatinine ratio and association with progression to endstage renal disease and mortality," The Journal of the American Medical Association, vol. 305, no. 15, pp. 1545-1552, 2011.

[52] M. Madero, C. L. Wassel, C. A. Peralta et al., "Cystatin C associates with arterial stiffness in older adults," Journal of the American Society of Nephrology, vol. 20, no. 5, pp. 1086-1093, 2009.

[53] M. Odaira, H. Tomiyama, C. Matsumoto et al., "Association of serum cystatin $\mathrm{C}$ with pulse wave velocity, but not pressure wave reflection, in subjects with normal renal function or mild chronic kidney disease," American Journal of Hypertension, vol. 23, no. 9, pp. 967-973, 2010.

[54] S. H. Song, I. S. Kwak, Y. J. Kim et al., "Serum cystatin C is related to pulse wave velocity even in subjects with normal serum creatinine," Hypertension Research, vol. 31, no. 10, pp. 1895-1902, 2008.

[55] Censo Nacional 2011, http://www.ine.gub.uy/censos2011/index .html. 


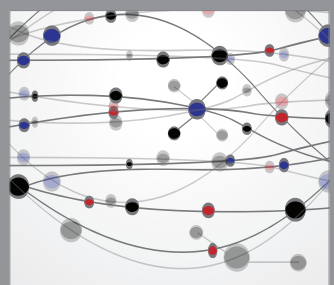

The Scientific World Journal
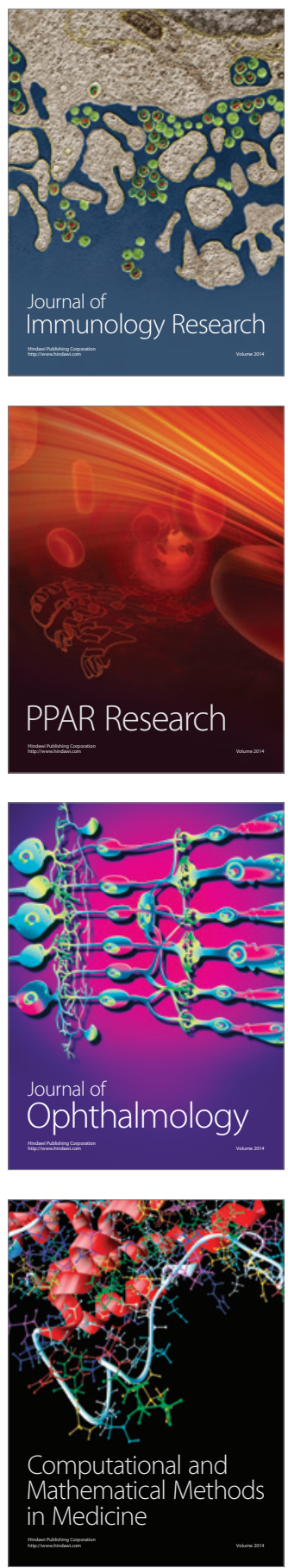

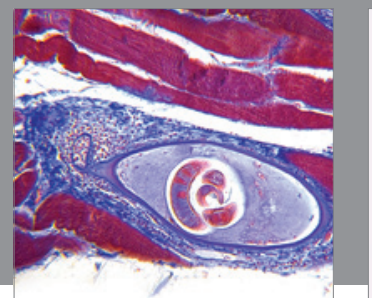

Gastroenterology

Research and Practice
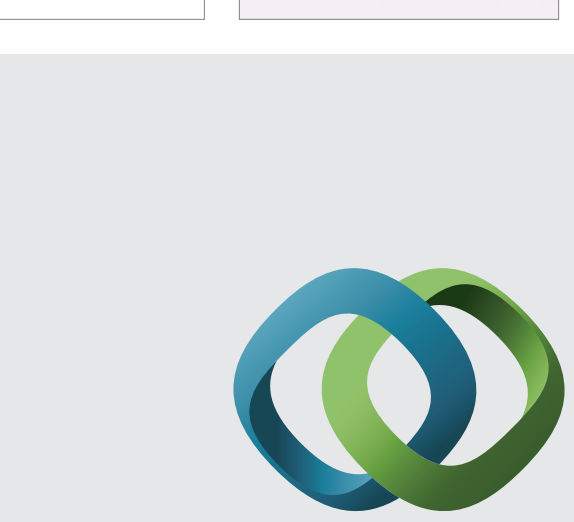

\section{Hindawi}

Submit your manuscripts at

http://www.hindawi.com
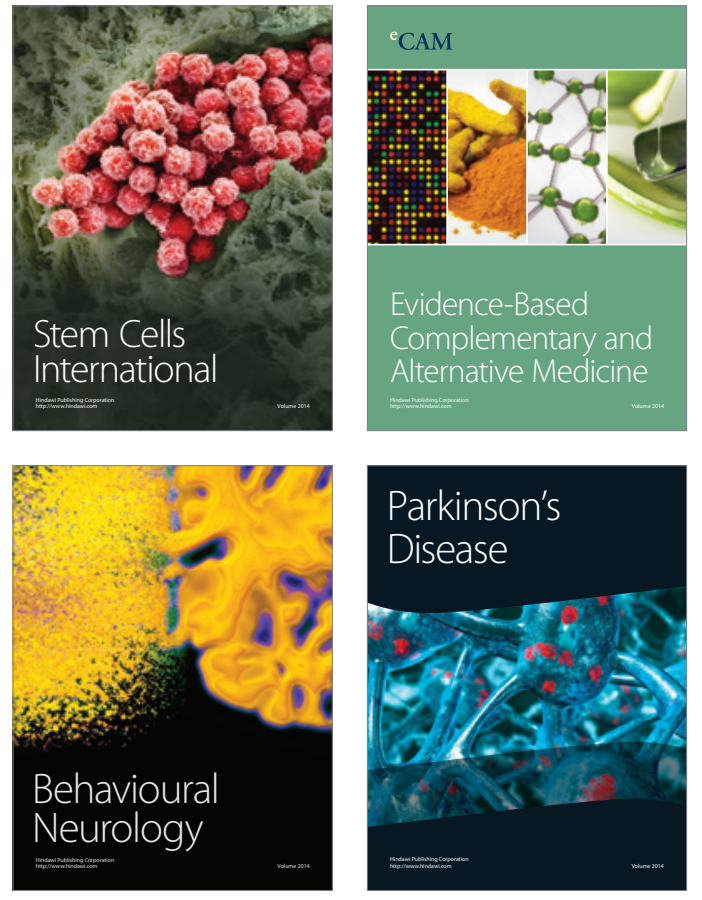
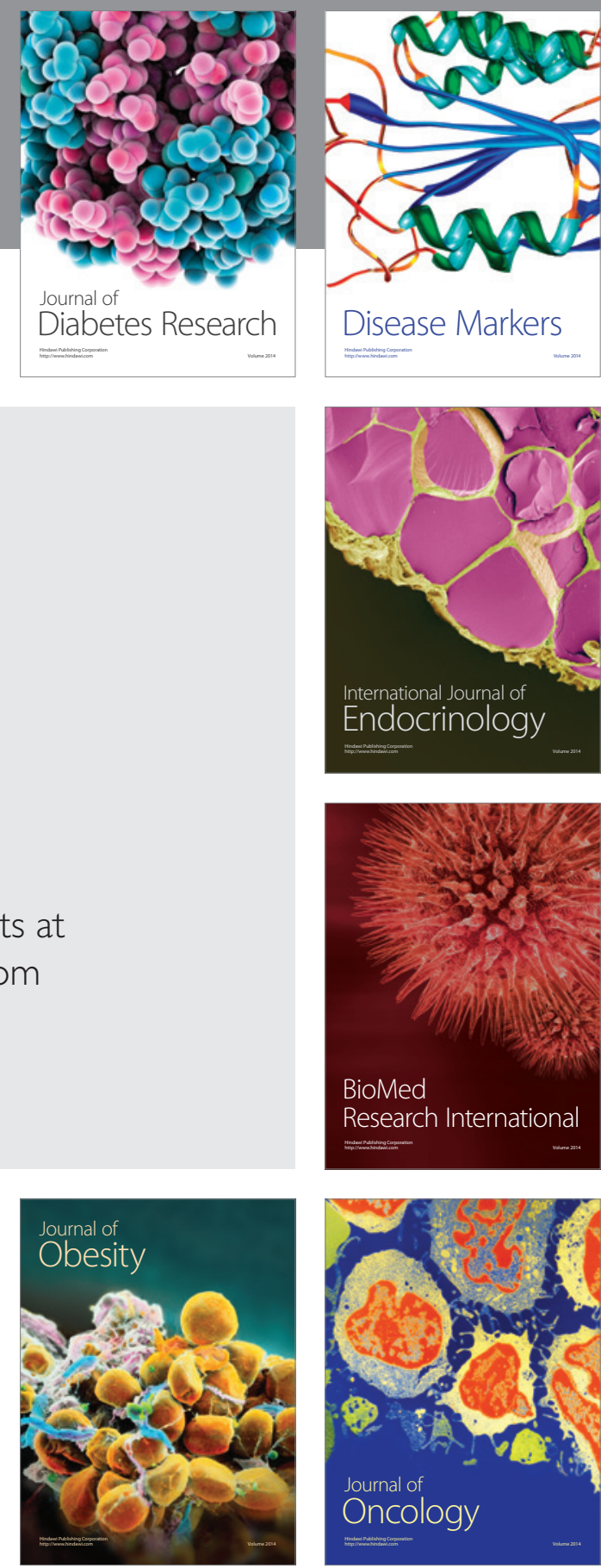

Disease Markers
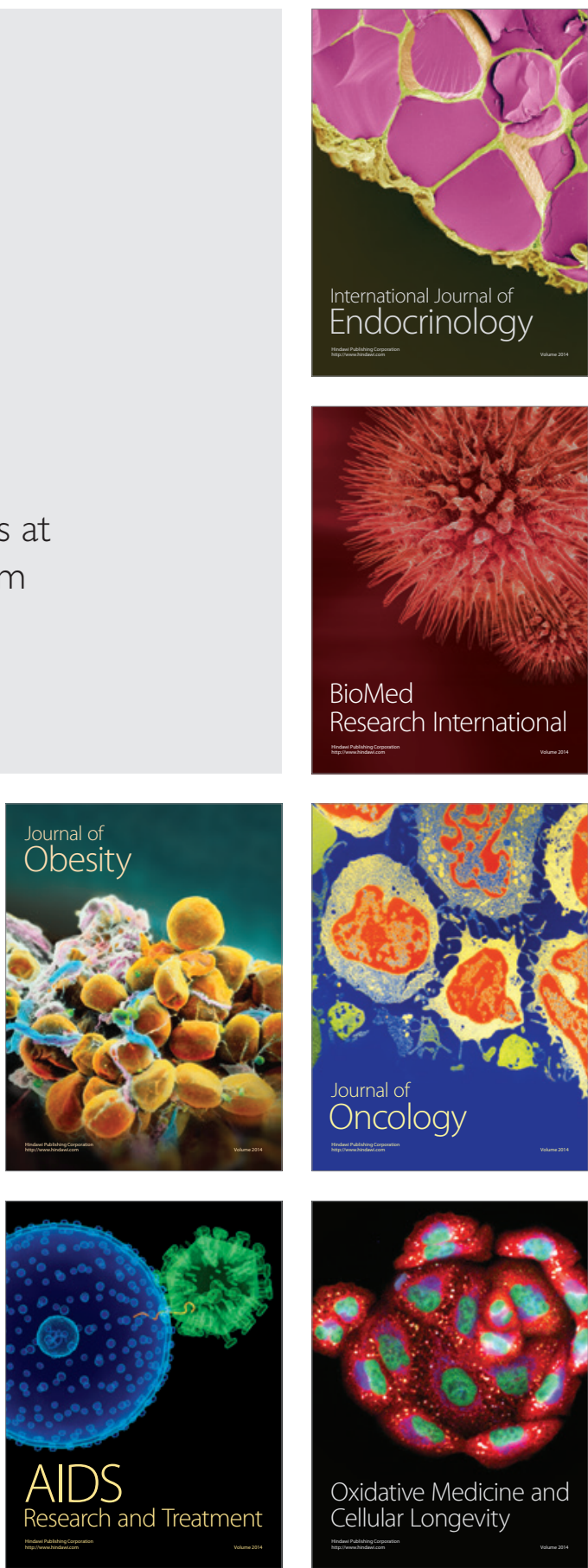